\title{
The Role of Human Operators in Safety Perception of AV Deployment-Insights from a Large European Survey
}

\author{
Miltos Kyriakidis ${ }^{1, *}$, Jaka Sodnik ${ }^{2}$, Kristina Stojmenova ${ }^{2}$, Arnór B. Elvarsson ${ }^{3} \mathbb{1}$, \\ Cristina Pronello ${ }^{4,5}$ (i) and Nikolas Thomopoulos ${ }^{6}$ \\ 1 Laboratory for Energy Systems Analysis, Paul-Scherrer Institute, 5232 Villigen, Switzerland \\ 2 ICT Department, Faculty of Electrical Engineering, University of Ljubljana, 1000 Ljubljana, Slovenia; \\ jaka.sodnik@fe.uni-lj.si (J.S.); kristina.stojmenova@fe.uni-lj.si (K.S.) \\ 3 Infrastructure Management Consultants, 8008 Zürich, Switzerland; arnor.elvarsson@gmail.com \\ 4 Interuniversity Department of Regional and Urban Studies and Planning, Politecnico di Torino, \\ 10125 Torino, Italy; cristina.pronello@polito.it \\ 5 Université de Technologie de Compiègne, Sorbonne Universités, EA 7284 AVENUES, \\ 60200 Compiègne, France \\ 6 Department of Tourism and Transport, School of Hospitality and Tourism Management, University of Surrey, \\ Guildford, Surrey GU2 7XH, UK; chair@wise-act.eu \\ * Correspondence: miltiadis.kyriakidis@psi.ch
}

Received: 1 September 2020; Accepted: 31 October 2020; Published: 4 November 2020

check for updates

\begin{abstract}
Autonomous vehicles are anticipated to play an important role on future mobility offering encouraging solutions to today's transport problems. However, concerns of the public, which can affect the AVs' uptake, are yet to be addressed. This study presents relevant findings of an online survey in eight European countries. First, 1639 responses were collected in Spring 2020 on people's commute, preferred transport mode, willingness to use AVs and demographic details. Data was analyzed for the entire dataset and for vulnerable road users in particular. Results re-confirm the long-lasting discourse on the importance of safety on the acceptance of AVs. Spearman correlations show that age, gender, education level and number of household members have an impact on how people may be using or allowing their children to use the technology, e.g., with or without the presence of a human supervisor in the vehicle. Results on vulnerable road users show the same trend. The elderly would travel in AVs with the presence of a human supervisor. People with disabilities have the same proclivity, however their reactions were more conservative. Next to safety, reliability, affordability, cost, driving pleasure and household size may also impact the uptake of AVs and shall be considered when designing relevant policies.
\end{abstract}

Keywords: safety; automated driving vehicles; vulnerable road users; user preferences; supervision; privacy; reliability; sustainability

\section{Introduction}

Safety, closely followed by economic and environmental benefits, are the most common positive effects associated with the arrival of automated vehicles (AVs). This is somewhat expected as AVs, especially those with higher levels of automation, are expected to increase safety by reducing the human role in driving, which has been reported to contribute to over 90 percent of all road traffic accidents [1-3]. In this paper, we adopt the SAE International, previously known as Society of Automotive Engineers (SAE), levels of driving automation [4]. The SAE is arguably the most well-known and broadly used taxonomy in the field of automated driving research [5], despite the existence of diverse views in the 
literature [6]. SAE provides six levels of vehicle automation according to the technological capabilities and human involvement in the driving tasks, from complete driver control over the vehicle (level 0) to fully automated vehicle, where no manual interaction is needed (level 5), also known as fully automated and/or autonomous (hereafter will be called $\mathrm{AVs}$ ), and the connected vehicles are further expected to contribute to route optimization, time savings, improved fuel economy, reduced traffic jams, lower costs and increased productivity due to the role change from driver to passenger [5,7-9]. Thus, it is eventually anticipated that AVs can be associated with broader sustainability objectives such as the UN Sustainable Developments Goal 11: Sustainable Cities and Communities, given their potential benefits [10].

However, despite all of the foreseen benefits of AVs, numerous surveys have offered contradictory findings regarding their acceptance among the general population [11-14]. Aimed at shedding some light on the diverse findings, this study explores the users' anticipation of AV safety and their overall perspective on AVs. For instance, Rödel et al. [12] pointed out that when referring to acceptance of AVs, the majority of research to date does not specify the level of automation, as defined by SAE [4]. Instead, research focuses on the general term of vehicle automation, which may result in confusion and uncertainty regarding problem framing. Indeed, the lack of specification of the level of automation has induced neglect of the transition phase from conventional vehicles (introduced in the 20th century) to automated vehicles anticipated to be widely used in the 21st century, which clearly is unrealistic given the extended period required for such a transition. Whilst studies report that travelers (i.e., potential $\mathrm{AV}$ users in the future) globally have an overall positive attitude towards AVs [13], it was also shown that their user experience (UX) and user acceptance (UA) change in relation to each level of automation, with most positive results related to lower automation levels which drivers are already familiar with [12].Hence, this article takes the debate among academics and practitioners on the deployment of $\mathrm{AVs}$ to the next level and highlights the illusion of solely stressing potential safety impacts. This article provides an evidence-based response to the proposition of widely deploying AVs even if they offer lower levels of safety [15]. Consequently, the potential benefits which may be introduced by AVs, including safety, have not yet convinced a large proportion of the general public-i.e., potential future $\mathrm{AV}$ users - to overcome their reservations towards fully automated vehicles, clearly indicating that there are other factors to be identified and addressed aside from technological advancements [11,14-16]. Among others, legal liabilities, data management, reduced comfort, relinquishment of control of the vehicle, increased cost, as well as familiarization and management with such advanced automated systems, have been reported in the literature [13,16-19].

The increased interest in the different facets of automated driving technology has led to several initiatives worldwide. Among other actions, the WISE-ACT COST Action [20] was funded by the H2020 Framework program. WISE-ACT aims at investigating the wider impacts of Autonomous and Connected Transport, focusing on SAE Level 5 of automated driving vehicles, and describing the best practice on how to evaluate them. To address its overarching aim, one of the main WISE-ACT objectives is to assess user acceptability and inform the general public and key stakeholders about the opportunities and risks of automated and connected transport (ACT).

Within the context of the WISE-ACT research objectives on tackling user acceptability, this study explores the factors that can impact public decision-making on using SAE Level 5 AVs, beyond safety concerns and trust in automation [21]. This article accounts for the opinion of vulnerable road users (VRUs), mainly of the elderly and people with disabilities. VRUs are defined here as "non-motorised road users, such as pedestrians and cyclists as well as motor-cyclists and persons with disabilities or reduced mobility and orientation" [22]. These potential AVs users may be among those benefitting the most from the widespread AV deployment [23]; yet, the elderly, people with disabilities and parents with young children belong to the most vulnerable social groups in terms of new technology acceptance given the interdependency of transport provision within households [24,25].

The remainder of this article is structured in the following way. Section 2 reviews related work and research to pinpoint the most important findings regarding the factors influencing vulnerable 
road users or their carers' willingness of, or reluctance to, use AVs. Section 3 presents the method, while Section 4 present and discuss the findings of the international WISE-ACT 2020 AV survey of the general public about the topic in focus, aimed at determining correlations of particular points of view with different socio-demographic characteristics, mainly focusing on parents and the elderly. Finally, Section 5 discusses relevant survey findings along with the contribution extent of each factor identified on the overall attitude of travellers towards AVs, shedding light on a range of important factors beyond safety to meet global sustainability goals.

\section{Identified Opportunities and Risks of AVs for Vulnerable Road Users}

AVs offer vast opportunities to improve transport and accessibility for a wide range of travellers [26]. However, not all AV impacts are positive or foster sustainability given the reported AV impacts; lack of privacy and/or comfort [27], for instance, are an ever-growing focus within decision-makers' policy agenda globally. Driving equates to independence, very frequently social interaction, freedom of choice, leisure, status and often facilitates basic household needs in most of the countries across the globe. Subsequently, the hype surrounding AVs is certainly understandable [28,29]. The importance of these factors has further grown within the COVID-19 context, where social distancing and the increased demand for the delivery of goods increased significantly [30,31].

Nonetheless, significantly less attention has been given to date on travel independence of vulnerable road users (VRUs). AVs are undeniably posed as a panacea for such social groups [32]. Children, the elderly, the visually-impaired and people with deteriorating and reduced cognitive, motoric and sensory skills are among those potential users who would benefit significantly from a self-driving and fully automated vehicle [23,25]. For example, parents, especially those living in suburban neighbourhoods, perceive AVs as a convenient transport alternative for their children to travel to and from school and their extracurricular activities [33-35]. Nonetheless, a previous study [36] found that only a small minority would allow their children to travel unaccompanied in an AV, which is in alignment with our findings shown in Section 4.

Among the most important risks for parents considering AVs as a transport mode for their children are the lack of control, which they would otherwise have themselves while driving, such as checking whether a seatbelt is on, automatically locking the doors, being aware of everyone else inside or near the vehicle and being able to stop the vehicle if the child for some reason does request it [33,34]. To ease these concerns, parents would like AVs to offer constant audio and preferably video control features, vehicle location tracking and secure passenger identification at all times [33], suggesting that although parents may have a positive attitude toward using AVs, their concerns are not related to the technology but rather the lack of control and supervision of the vehicle. Adding a large number of remote-control features to an AV is feasible from a technological perspective [35], however it does raise questions regarding whether automated transport for children would still offer the initially anticipated benefits, if a parent or carer would need to be, even if only virtually, still constantly present and in control of each journey. A more feasible scenario, at least during the early transition stages, may be the age limit of AV travellers [33]. Age limit could be aligned with the law for acceptable age for letting a child alone at home, which in some states in the US, for instance, has been defined to be the age of eight years old [37].

Equally, travel needs of the elderly, whose deteriorating sensory, motoric and/or cognitive abilities can affect their driving skills and road safety, appear as another example featured in the AV literature [38,39]. Vision, hearing, muscular strength, speed of muscle contraction and flexibility decrease with aging, reducing an individual's capability of safely operating and controlling a vehicle. However, advanced driver assistant systems (ADAS) can contribute to resolving a lot of these sensory-motoric issues [38]. A more complex safety related problem however lays in the age-related changes in cognitive functions such as attention, memory, information processing and decision-making [39], which are critical for safe driving and interaction with in-vehicle information systems [40]. While a fully automated vehicle (SAE Level 5) will completely takeover the driving 
task, there would still be a need for human-computer interaction (HMI), where the elderly person using an AV may have to communicate with the selected vehicle and provide their journey details, such as destination, route including desired stops, speed, urgency or parking preferences. Given the fact that the primary need for use of an AV for this user group would largely be the deterioration of cognitive skills, it is questionable whether acquiring all the required skills to use and operate an $\mathrm{AV}$ would be a much simpler task in all situations without increasing their personal security or safety risks. For instance, elderly users of conventional taxis are able to communicate their needs at all times with the driver; it is still unclear, however, how such interaction will be ensured in AVs, as human machine interfaces or communication systems with an external operator/supervisor might not be perceived equivalent to speaking directly with a human operator who is physically present in the vehicle. A recent study on AV bus users in Stockholm showed that users felt much safer with an operator or steward on-board the AV bus in comparison to not [41].

Another important factor intertwined with equity concerns [42] is linked with the relatively high costs associated with the use of AVs, at least for the time being [43]. To operate in a fully automated mode, $\mathrm{AVs}$ are equipped with a wide range of advanced sensors and processing algorithms, which significantly increase the cost of production compared to a conventional vehicle. Yet, evidence from early surveys worldwide revealed that, on average, respondents across the general public would not pay more for an automated vehicle than they would for a non-automated one. These results are displayed in Table 1.

Table 1. Share of respondents not willing to pay more for an automated vehicle than conventional vehicle.

\begin{tabular}{ccccccccc}
\hline & China & India & New Zealand & Australia & USA & UK & Japan & World * \\
\hline Share & $21 \%$ & $29 \%$ & $30 \%$ & $55.2 \%$ & $54.5 \%$ & $59.8 \%$ & $67 \%$ & $22 \%$ \\
\hline \multicolumn{7}{c}{$*$ Based on an international study of 109 countries. Sources: $[11,13,44]}$.
\end{tabular}

These studies have certain limitations, but still offer helpful preliminary findings highlighting the need for more context specific and better coordinated survey approaches about such a core issue. For instance, clear discrepancies are observed among the willingness of people living in different countries. In fact, residents of the Global North, with the exception of New Zealand, seem to be less inclined to pay more for an $\mathrm{AV}$ compared to the amount they would pay for a conventional vehicle [43]. On the contrary, residents in countries of the Global South, which have higher number of accidents, are willing to pay more for an AV anticipating increased safety on public roads.

Another limitation of these studies is that they do not link their findings about willingness-to-pay for the use of AVs with disposable income, at least at the national level. Especially for the elderly, it is important to consider that they rely largely on diverse public and private pension schemes often providing disposable incomes below the national average. Hence, the affordability of using AVs, particularly by VRUs, is another key issue in addition to safety concerns. Cost was also reported as one the major concerns among parents, when asked about the most important attitudes of using AVs for their children's travel compared to security and privacy, lack of independence and boredom [34].

On the other hand, shared mobility solutions have been reported as an option to reduce the individual cost of AVs for the users. Yet, a study in Israel and North America found that even if $\mathrm{AV}$ use would be completely free, $25 \%$ of the population would still not use them [17]. The elderly are overall more favourable to use shared mobility, as long as it can cover their needs [45]. Nonetheless, the advanced digital skills needed for using AVs, e.g., via Mobility as a Service (MaaS) platforms, as well as the challenges posed by the COVID-19 pandemic globally, revealed a further pitfall of shared mobility [46]. Given the risks of shared vehicles, services and infrastructure suddenly turned into a major disadvantage of such options (e.g., MaaS) due to the greater exposure to a potential infection, affecting the people's positive attitudes towards automated and shared mobility systems [46].

Consequently, this article shows that safety is not the only factor that may affect the acceptance and trust of the public towards using AVs. Instead and in line with contemporary academic literature [43], 
our findings show that reliability, usefulness and affordability, as well as the presence of a supervisor in the vehicle or remotely can affect the public's acceptance towards automated technology. This article provides valuable insights on the factors which influence key design and deployment issues of AVs policies besides safety, with a particular emphasis on vulnerable road users.

\section{Method}

To shed light on the reasons which may lead to a limited or delayed transition of widespread use of AVs, the research investigated the user perception in different European countries participating in WISE-ACT. To this end, a three-step approach was comprised of: (1) survey design; (2) sample selection and survey administration; (3) data analysis design.

\subsection{Survey Design}

The survey consisted of a web-questionnaire consisting of three sections:

- the first section focuses on three main aspects:

- $\quad$ revealed preferences data about the daily mobility with focus on the most important trip (purpose and mode) and the reason why the selected mode has been chosen; details about number of accidents by car in the last three years and the use of Adaptive Cruise Control while driving a car in the last 12 months;

- mobility attitudes related to most important trip;

- information about knowledge and perception and acceptance of autonomous vehicles for passengers (including children) and goods and expected effects;

- the second section focuses on two main aspects:

- an insight about a regular journey considered while completing this survey section;

- $\quad$ stated preferences about different options of autonomous vehicles (private or shared vehicle);

- the last section focuses on collecting socio-economic characteristics of each respondent.

A definition of the AVs was introduced to the participants to avoid any misunderstanding of the notion, i.e., "An Autonomous Vehicle (AV) is a vehicle which takes over speed and steering control completely and permanently, on all roads and in all situations ". Respondents were asked to consider a fully automated vehicle, i.e., an autonomous vehicle according to SAE Level 5. The survey received ethical approval and all data collected were in an anonymous format.

The variables used in this article were derived from the first and third sections, focusing on variables related to safety, involvement in accidents in the last three years, anticipated impacts of $\mathrm{AVs}$, use of AVs by vulnerable groups (e.g., children) and socio-demographics, including household members in need of care. Table 2 includes some of the selected variables with the related unit of measure. A six-point Likert scale was used for attitudinal variables and those measuring user perceptions and preferences, in line with contemporary research [47]. 
Table 2. Description of selected variables.

\begin{tabular}{|c|c|c|}
\hline Variable Name & Description of the Variables & Range of Values \\
\hline \multirow[t]{3}{*}{ Current travel choices } & $\begin{array}{l}\text { Think of a typical week of yours. What is } \\
\text { the purpose of the most important } \\
\text { journey of yours? }\end{array}$ & Categorical variable \\
\hline & $\begin{array}{l}\text { What is the main mode of transport you } \\
\text { use for this important journey of yours? }\end{array}$ & Categorical variable \\
\hline & $\begin{array}{l}\text { I choose ... as my main transport mode } \\
\text { because of the... (e.g., reliability, arriving } \\
\text { at the expected time) }\end{array}$ & $\begin{array}{l}\text { Judgment on the statement, expressed } \\
\text { through a Likert scale by a score from } 1 \\
\text { (total disagreement) to } 6 \text { (total agreement) }\end{array}$ \\
\hline \multirow[t]{2}{*}{$\begin{array}{l}\text { Safety and exposure } \\
\text { to technology }\end{array}$} & $\begin{array}{l}\text { How many accidents have you been } \\
\text { involved in while driving a car in the last } \\
3 \text { years? }\end{array}$ & Discrete variable \\
\hline & $\begin{array}{l}\text { How often did you use Adaptive Cruise } \\
\text { Control while driving a car in the last } \\
12 \text { months? }\end{array}$ & Categorical variable \\
\hline \multirow[t]{2}{*}{ Willingness to use AVs } & $\begin{array}{l}\text { I would travel in an } \mathrm{AV} \text { (e.g., car, taxi, bus) } \\
\text { with (without) supervision of a human } \\
\text { operator in the vehicle (at distance) }\end{array}$ & $\begin{array}{l}\text { Judgment on the statement, expressed } \\
\text { through a Likert scale by a score from } 1 \\
\text { (total disagreement) to } 6 \text { (total agreement) }\end{array}$ \\
\hline & $\begin{array}{l}\text { I would allow my children to travel in an } \\
\text { AV (e.g., car, taxi, bus) with (without) } \\
\text { supervision of a human operator in the } \\
\text { vehicle (at distance) }\end{array}$ & $\begin{array}{l}\text { Judgment on the statement, expressed } \\
\text { through a Likert scale by a score from } 1 \\
\text { (total disagreement) to } 6 \text { (total agreement) }\end{array}$ \\
\hline Expectations & $\begin{array}{l}\text { AVs will increase (decrease) e.g., road } \\
\text { accidents, traffic congestion, driving } \\
\text { pleasure, time for non-driving activities, } \\
\text { mobility for all etc. }\end{array}$ & $\begin{array}{l}\text { Judgment on the statement, expressed } \\
\text { through a Likert scale by a score from } 1 \\
\text { (total disagreement) to } 6 \text { (total agreement) }\end{array}$ \\
\hline
\end{tabular}

\subsection{Sample Selection and Administration}

The sample was based on a snowballing technique via key WISE-ACT stakeholders at the national and local levels (interest groups, public transport providers, national road agencies, engineer's organizations, normal citizens). The survey was designed in English and then translated into 7 languages to be administered in the selected 8 countries.

This article focuses on the responses from the eight countries, Cyprus, Finland, Greece, Iceland, Italy, Malta, Montenegro, Slovenia, representing EU, EEA and non-EU/EEA countries of different population, geographical size, geomorphology, GDP and transport infrastructures. A wide range of individuals have been contacted to cover the following sampling criteria: gender, age, transport mode used, education level and size of household, as well as any known disabilities, reaching the 2876 respondents distributed across the countries, as shown in Table 3.

Table 3. Number of responses per country.

\begin{tabular}{lccccccccc}
\hline & Total & Cyprus & Greece & Finland & Iceland & Italy & Montenegro & Malta & Slovenia \\
\hline Response records & 2876 & 257 & 232 & 170 & 1068 & 171 & 464 & 51 & 463 \\
Analyzed records & 1639 & 158 & 128 & 101 & 561 & 78 & 309 & 26 & 278 \\
\hline
\end{tabular}

The sample forms a unique dataset in terms of geographical and cultural coverage which has not been analyzed before.

\subsection{Data Analysis Design}

Data analysis included the following steps: 
- database building, variable encoding, outlier detection and check of validity and completeness of responses. This analysis allowed us to define the database for this analysis (Figure 1), formed by 1639 valid answers out of 2876 received;

- $\quad$ statistical descriptive analysis focused mainly on characterizing the sample of respondents;

- calculation of Spearman correlation coefficients between age, gender, use of transport mode, education, accidents, number of people in the household, number of dependents in the household, disability and use of ACC (Adaptive Cruise Control), on the one hand, and the willingness to travel in an $\mathrm{AV}$, and the willingness to allow children to travel in an $\mathrm{AV}$, on the other.

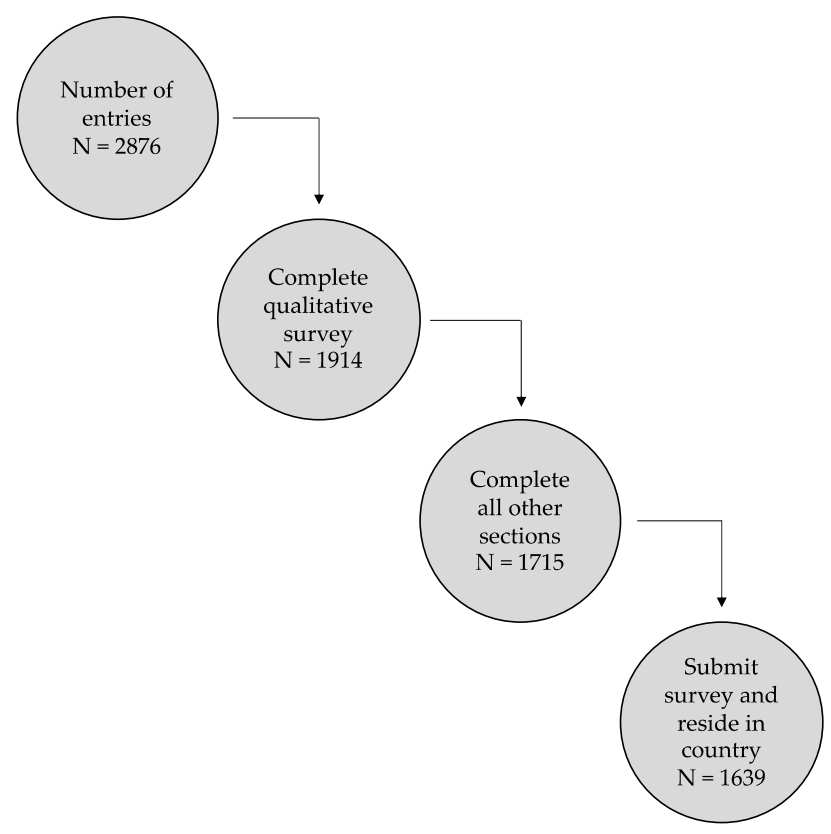

Figure 1. Dataset formulation based on total survey responses received.

\section{Results}

The sample of 1639 valid responses included a majority of male respondents, $68.7 \%$ (1126 men and 508 women, while 5 participants identify themselves otherwise); in Table 4, the socio-economic characteristics of the sample together with level of reduced mobility are presented. Overall, the sample is quite balanced regarding age, despite an unavoidably higher representation of those within the 20-49 age groups and similarly regarding employees. Section 4.1 reports the descriptive analysis of the questions on which this paper is focused, listed in Table 2. Additional descriptive statistics on the survey's questions are included in Tables A1-A4, in Appendix A. Section 4.2 reports the analysis of correlations among the variables to better understand how socio-economic characteristics of the sample matter as regards their potential use and perception of AVs. Finally, Section 4.3 focuses on the attitudes of vulnerable road users towards AVs with special attention to elderly people ( $>65$ years old), and people with disabilities. 
Table 4. Descriptive statistics of participants.

\begin{tabular}{|c|c|c|c|}
\hline & & Total & Share \\
\hline & & 1639 & $100 \%$ \\
\hline \multirow{3}{*}{ Sex } & Male & 1126 & $68.7 \%$ \\
\hline & Female & 508 & $31.0 \%$ \\
\hline & Other & 5 & $0.3 \%$ \\
\hline \multirow{10}{*}{ Age } & younger than 16 & 1 & $0.1 \%$ \\
\hline & $16-19$ & 45 & $2.7 \%$ \\
\hline & $20-29$ & 487 & $29.7 \%$ \\
\hline & $30-39$ & 325 & $19.8 \%$ \\
\hline & $40-49$ & 330 & $20.1 \%$ \\
\hline & $50-59$ & 219 & $13.4 \%$ \\
\hline & $60-69$ & 161 & $9.8 \%$ \\
\hline & $70-79$ & 50 & $3.1 \%$ \\
\hline & $80+$ & 7 & $0.4 \%$ \\
\hline & Did not disclose & 14 & $0.9 \%$ \\
\hline \multirow{7}{*}{ Current employment status } & Employee & 983 & $60.0 \%$ \\
\hline & Self-employed & 149 & $9.1 \%$ \\
\hline & Company owner & 47 & $2.9 \%$ \\
\hline & Unemployed & 94 & $5.7 \%$ \\
\hline & Full-time education & 247 & $15.1 \%$ \\
\hline & Retired & 86 & $5.2 \%$ \\
\hline & Other & 33 & $2.0 \%$ \\
\hline \multirow{5}{*}{ Highest educational degree } & $\begin{array}{c}\text { Primary school or } \\
\text { equivalent }\end{array}$ & 9 & $0.5 \%$ \\
\hline & High-school & 351 & $21.4 \%$ \\
\hline & College/University & 761 & $46.4 \%$ \\
\hline & Postgraduate & 487 & $29.7 \%$ \\
\hline & Other & 31 & $1.9 \%$ \\
\hline \multirow{5}{*}{ Mobility-reducing disabilities } & $\begin{array}{l}\text { No known } \\
\text { disability }\end{array}$ & 1416 & $86.4 \%$ \\
\hline & Mobility issue & 37 & $2.3 \%$ \\
\hline & Visual impairment & 16 & $1.0 \%$ \\
\hline & Other & 73 & $4.5 \%$ \\
\hline & Does not disclose & 97 & $5.9 \%$ \\
\hline \multirow{2}{*}{ Driving license } & Yes & 1551 & $94.6 \%$ \\
\hline & No & 88 & $5.4 \%$ \\
\hline
\end{tabular}

\subsection{Mobility Habits, AV Knowledge and Acceptance}

Concerning the mobility habits of our sample, the majority of participants (58\%) indicated that their most important daily journey is to go to work, while $68 \%$ indicated that they use a private car for this journey. Respondents, as shown in Figure 2, highlighted that the travel time to reach their destination is the most important factor for them when choosing their transport mode $(\mathrm{M}=4.46$, on a scale from $1=$ Strongly Disagree to $6=$ Strongly Agree), followed by the reliability of the transport mean ( $\mathrm{M}=4.42$, on the same scale). 


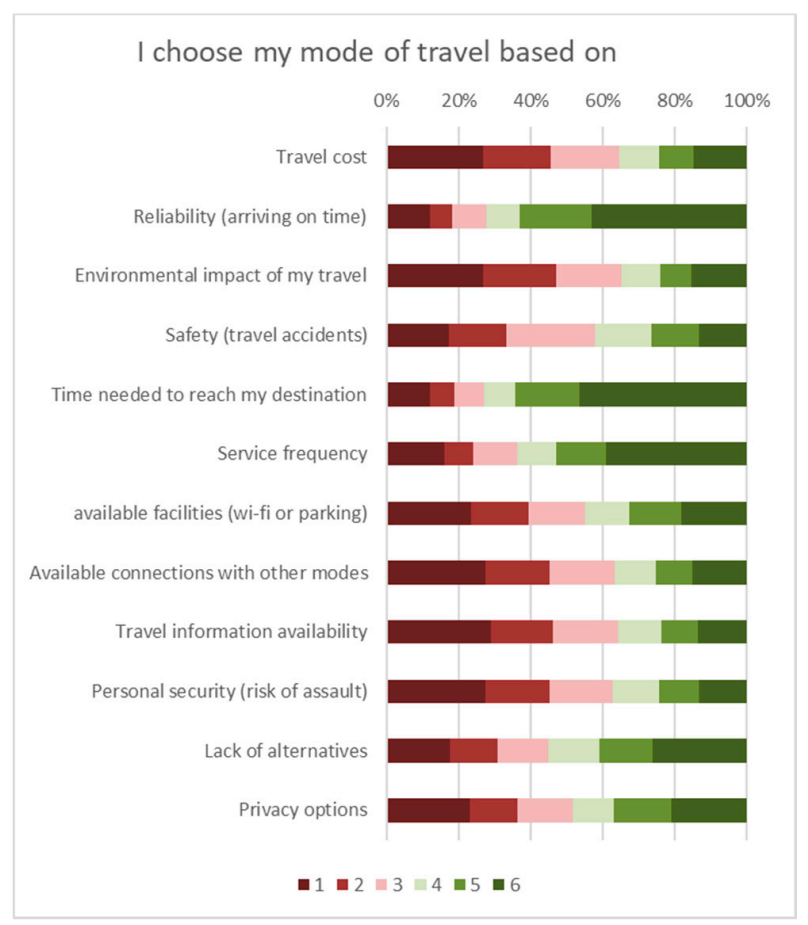

Figure 2. Factors affecting mode choice ( $1=$ Strongly disagree, $6=$ Strongly agree).

$76 \%$ of the survey respondents claimed to have heard, read or seen information about AVs in the last 12 months, which is a sharp increase compared to the findings (52.2\%) presented in Kyriakidis et al. [11]. This increase justified the need to revisit relevant issues in 2020, hence building up on the hype surrounding $\mathrm{AVs}$ and the technological advancements in the preceding five years.

People were also asked to express their comfort in the presence of an AV. Their responses are shown in Figure 3. Results showed that people, on average, would not feel uncomfortable in the presence of an $\mathrm{AV}$, especially if they were either travelling in a conventional vehicle $(\mathrm{M}=3.69)$ or passengers in an $\mathrm{AV}(\mathrm{M}=3.70)$.

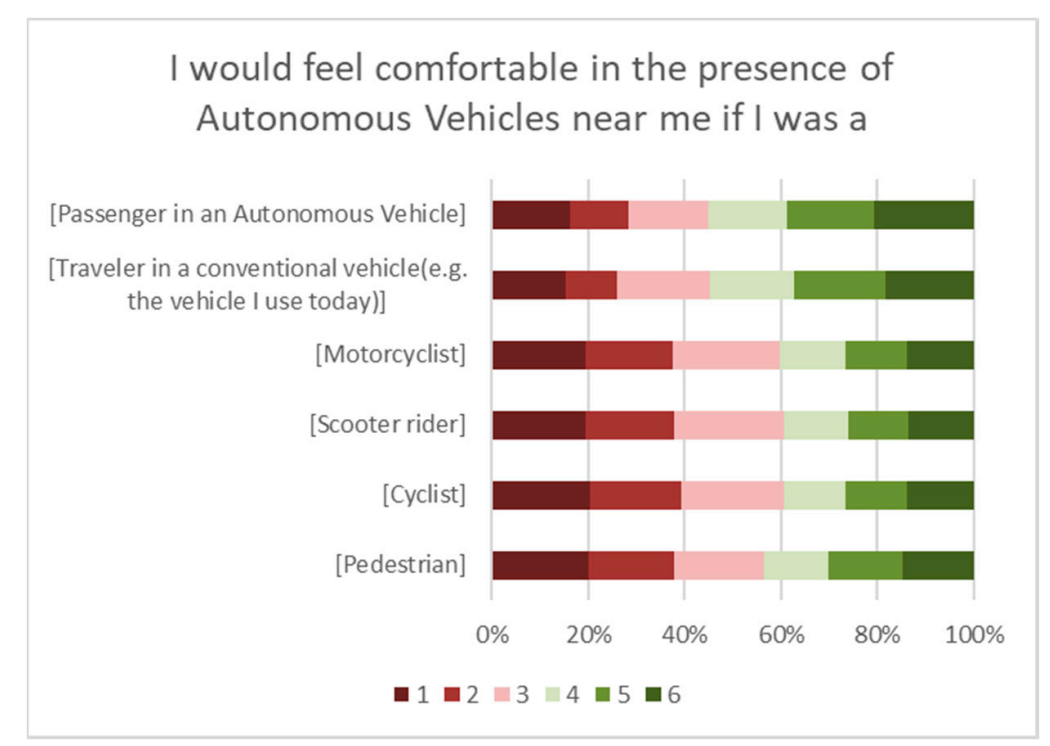

Figure 3. Response on participants' comfort level in the presence of an AV (on a scale from $1=$ Strongly disagree to $6=$ Strongly agree). 
Respondents were also asked to describe the conditions in which they would be willing to travel in an AV or allow their children to travel in an AV. Results revealed that people would be largely willing to travel in $A V$ in the presence of a human operator inside the vehicle $(M=4.15)$. Similarly, people indicated that they would allow their children to travel in an AV if a human operator was in the vehicle $(M=4.0)$. On the other hand, they were quite reluctant to travel in an AV without the supervision of a human operator either inside the vehicle $(M=3.47)$ or remotely $(M=3.21)$, while they were rather sceptical about allowing their children travelling in an $\mathrm{AV}$ without the supervision of a human operator $(\mathrm{M}=2.92)$.

Survey participants also indicated that safety and reliability are the main drivers for their decision to purchase an $\mathrm{AV}(\mathrm{M}=4.03$ and $\mathrm{M}=4.01$, respectively), which corresponds with the most important reasons for choosing to drive a car. The latter confirms the main argument of this paper, which is founded on the importance of safety for AVs deployment and not merely on their availability. Figure 4 shows the six questions exploring the point in time when a respondent would be willing to purchase an AV.

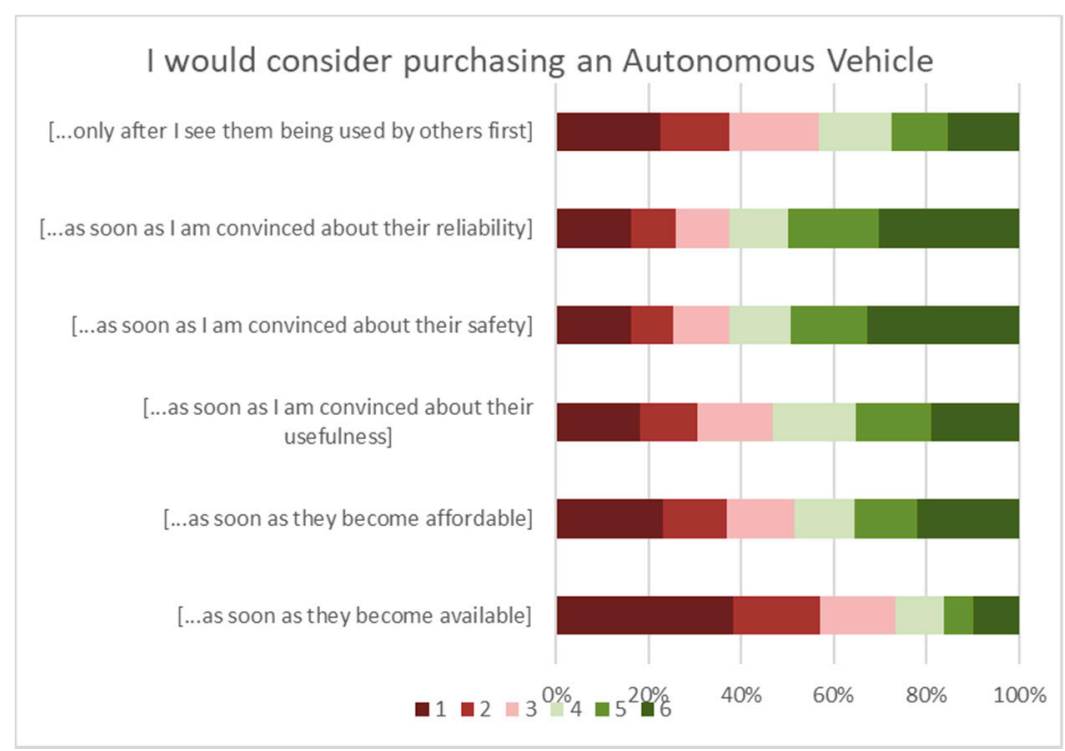

Figure 4. Response on participants' main drivers towards purchasing an AV (on a scale from $1=$ Strongly disagree to $6=$ Strongly agree).

Finally, information regarding respondents' expectations about the impacts of AV use were also asked, and responses are documented in Figure 5. Respondents largely anticipate AVs to allow them to engage in activities other than driving tasks $(\mathrm{M}=4.21$, fifth row in Figure 4) hence using their travel time more productively, while AVs are also anticipated to increase mobility for everyone $(M=4.20)$. Nevertheless, concerns were also raised across the sample countries. In particular, respondents are worried that $\mathrm{AVs}$ are likely to threaten the number of professional driving jobs $(\mathrm{M}=4.03)$ which is also aligned with the Eurobarometer 2020 survey findings which focused only on EU countries [48], while they will also reduce driving pleasure $(\mathrm{M}=3.65)$. 


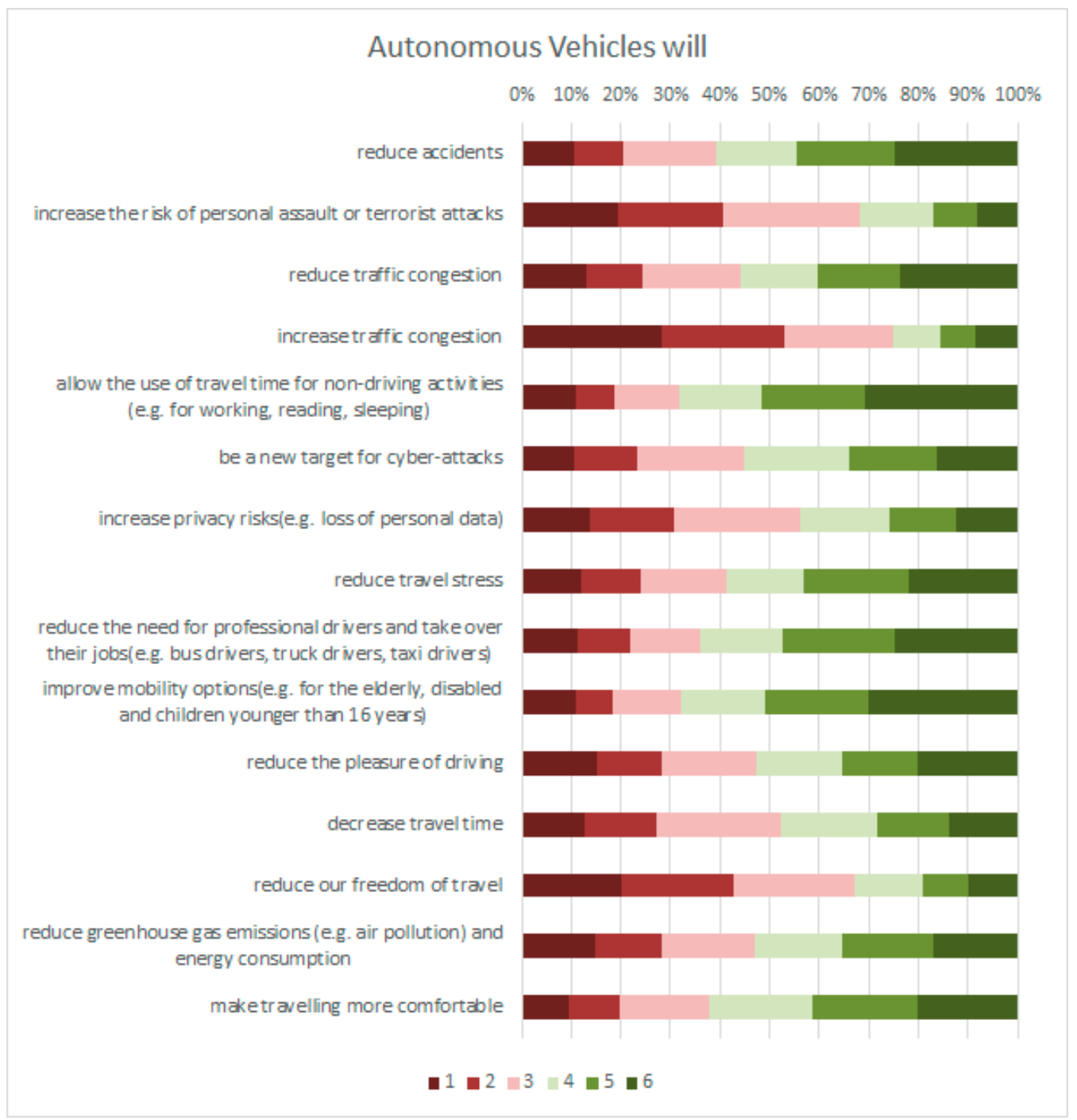

Figure 5. Respondents' beliefs regarding effects of autonomous vehicles (on a scale from 1 = Strongly disagree to $6=$ Strongly agree).

Lastly, findings addressed the point that elderly respondents would be willing to purchase an $\mathrm{AV}$ in order to explore the impact of safety among other factors on the decision. The intention of respondents to purchase an $\mathrm{AV}$ as soon as these become affordable was also explored and compared to the GDP per capita (nominal) for each of the eight countries. Although findings indicate a small association $(\rho=0.054, p<0.05)$, they also do show that the higher the GDP per capita the more positive respondents were towards purchasing an $\mathrm{AV}$ when these become affordable. No clear definition of affordability was provided to the respondents. Therefore, we assume that an affordable AV, in this instance, is equivalent to an affordable conventional vehicle, which naturally varies among the eight countries included in this survey.

\subsection{Correlation between Socio-Economic Variables and Use and Perception of AVs}

Table 5 shows the results of the Spearman correlation analysis and reports the coefficients related to the correlation between the socio-economic characteristics of the sample and their potential use and perception of AVs. 
Table 5. Spearman correlation table between reported impacts of AVs and sociodemographic attributes and reported past behaviour.

\begin{tabular}{|c|c|c|c|c|c|c|}
\hline & $\begin{array}{l}\text { Travel in an AV (e.g., } \\
\text { Car, Taxi, Bus) with } \\
\text { the Supervision of a } \\
\text { Human Operator in } \\
\text { the Vehicle }\end{array}$ & $\begin{array}{l}\text { Travel in an AV (e.g., } \\
\text { Car, Taxi, Bus) with } \\
\text { the Remote } \\
\text { Supervision of a } \\
\text { Human Operator at a } \\
\text { Distant Location }\end{array}$ & $\begin{array}{c}\text { Travel in an AV (e.g., } \\
\text { Car, Taxi, Bus) } \\
\text { without the } \\
\text { Supervision of a } \\
\text { Human Operator }\end{array}$ & $\begin{array}{l}\text { I Would Allow My } \\
\text { Children to Travel in } \\
\text { an AV (e.g., Car, Taxi, } \\
\text { Bus) with the } \\
\text { Supervision of a } \\
\text { Human Operator in } \\
\text { the Vehicle }\end{array}$ & $\begin{array}{c}\text { I Would Allow My } \\
\text { Children to Travel in } \\
\text { an AV (e.g., Car, Taxi, } \\
\text { Bus) with the } \\
\text { Remote Supervision } \\
\text { of a Human Operator } \\
\text { at a Distant Location }\end{array}$ & $\begin{array}{l}\text { I Would Allow My } \\
\text { Children to Travel in } \\
\text { an AV (e.g., Car, Taxi, } \\
\text { Bus) without the } \\
\text { Supervision of a } \\
\text { Human Operator }\end{array}$ \\
\hline Age & $0.134^{* *}$ & -0.008 & $-0.145^{* *}$ & $0.136^{* *}$ & -0.021 & $-0.176^{* *}$ \\
\hline Accidents in the last 3 years & $-0.086^{* *}$ & $-0.056^{*}$ & 0.013 & $-0.075^{* *}$ & -0.021 & 0.024 \\
\hline Transport mean & $-0.066^{* *}$ & -0.001 & 0.019 & $-0.051 *$ & 0.017 & 0.031 \\
\hline Gender & 0.005 & -0.025 & $-0.111 * *$ & -0.029 & $-0.061^{*}$ & $-0.127^{* *}$ \\
\hline Education & $0.096^{* *}$ & $0.049 *$ & $-0.076^{* *}$ & $0.066^{* *}$ & 0.007 & $-0.113^{* *}$ \\
\hline Members in household & $-0.127^{* *}$ & -0.017 & $0.076^{* *}$ & $-0.122 * *$ & 0.002 & $0.122 * *$ \\
\hline $\begin{array}{c}\text { Dependent members in } \\
\text { household }\end{array}$ & -0.014 & -0.014 & 0.032 & -0.064 * & -0.019 & 0.045 \\
\hline Disability & $0.154^{* *}$ & -0.012 & $-0.076^{* *}$ & $0.112 * *$ & -0.017 & $-0.113^{* *}$ \\
\hline ACC use & 0.042 & -0.002 & -0.010 & 0.033 & -0.012 & -0.006 \\
\hline
\end{tabular}

** Significant correlation at the 0.01 level, * significant correlation at the 0.05 level. 
Firstly, a clear effect of age can be observed on people's responses regarding the conditions under which they would travel in an AV or allow their children to travel in an AV. In fact, the older the participants the keener they are to travel in an AV with the presence of an operator in the vehicle. In contrast, the older the participants the more reluctant they are to use an AV without the physical or remote presence of an operator. Similar are the results regarding the effect of age on whether people would allow their children to travel in AVs, with both sets of findings offering valuable information regarding AV use by VRUs. Male participants seemed to be more open towards travelling in an $\mathrm{AV}$ without the supervision of human operators, while men also seem to be more positive towards allowing children in travelling in an AV with the remote supervision of a human operator or without the supervision of an operator.

Education also has an effect on people's responses to the question about the conditions in which they would travel in an AV or allow their children to travel in an AV. The more educated the participants (e.g., university or postgraduate degree) the more open they are on traveling in an AV with the presence of an operator in the vehicle or remotely. Conversely, the better educated respondents were found more reluctant to use AVs without the physical or remote presence of an operator. The number of household members also has an impact on responses. Specifically, people with fewer members in the household are more inclined to travel in an $\mathrm{AV}$ with the supervision of a human operator. On the other hand, respondents of larger households are more willing to travel in an AV without the supervision of a human operator. The same trends are also established regarding whether people would allow children to travel in an AV. Households with fewer members tend to be less likely to allow their children to travel in an AV without the supervision of human operator. On the contrary, households with more members are more positive on allowing children to travel in an $\mathrm{AV}$ without the supervision of an operator.

The previous experience and use of ACC have also an effect on both questions assessing the presence of a human operator in the vehicle. In fact, those who have been more rarely using an $\mathrm{ACC}$ indicate stronger intention to travel in an $\mathrm{AV}$ with the supervision of a human operator in the vehicle, clearly demonstrating a link between previous engagement with automated driving assistance technologies and AV use uptake.

1111 out of the 1639 valid cases indicated that they use a private vehicle for their most important daily journey, while179, 120 and 43 participants declared public transport, private bicycle and shared car or motorbike, respectively. Table 6 summarizes the findings on respondents' main driver for choosing a specific transport mode. It can be clearly seen that respondents prefer a private car for their journeys due to their reliability and time to reach the destination. On the other hand, neither the cost nor the impact of the vehicle on the environment seem to be strong drivers against this choice. In contrast, environmental implications and cost of transport are the main drivers for those choosing public transport for their commute. For those commuting by bicycle, the time to reach destination, cost, reliability and environmental implications are the stronger drivers behind their choice. However, to draw more concrete conclusions the average daily mileage of the commuters shall also be recorded. This will be part of a follow up study. Finally, no clear indication of a single specific reason could be found among those who prefer to travel in a shared car or a motorbike. 
Table 6. Statistics on main driver to choose transport mode for daily important journey.

\begin{tabular}{cccccccc}
\hline & & $\begin{array}{c}\text { Because } \\
\text { of Its Cost }\end{array}$ & $\begin{array}{c}\text { Because } \\
\text { of Its } \\
\text { Reliability }\end{array}$ & $\begin{array}{c}\text { Because of } \\
\text { Its Impact } \\
\text { on the } \\
\text { Environment }\end{array}$ & $\begin{array}{c}\text { Because of } \\
\text { Its Safety }\end{array}$ & $\begin{array}{c}\text { Because of } \\
\text { the Time } \\
\text { to Reach } \\
\text { Destination }\end{array}$ & $\begin{array}{c}\text { Because } \\
\text { of the } \\
\text { Service } \\
\text { Frequency }\end{array}$ \\
\hline \multirow{2}{*}{ Private car } & Med & 2 & 6 & 2 & 3 & 6 & 5 \\
& IQR & 3 & 2 & 2 & 3 & 2 & 3 \\
\hline \multirow{2}{*}{ Public transport } & Med & 4 & 3 & 4 & 3 & 3 & 4 \\
& IQR & 2 & 3 & 2 & 3 & 3 & 3 \\
\hline \multirow{2}{*}{ Private bicycle } & Med & 5 & 5 & 6 & 3 & 5 & 5 \\
\hline Shared car & IQR & 4 & 3 & 1.75 & 2 & 3 & 3 \\
\hline or motorbike & Med & 3 & 4 & 4 & 3 & 4 & 3 \\
\hline
\end{tabular}

\subsection{AVs Opinions and Perceptions of Vulnerable Road Users}

A more targeted analysis was conducted on vulnerable road users; in particular, the responses of individuals older than 65 years were analysed $(\mathrm{N}=117, \mathrm{M}=70.41)$ to capture the opinion and intentions of the "elderly" towards AVs. The findings in Table 7 offer valuable insight irrespective of the small proportion of this sub-sample compared to the overall survey sample, which, however, is in line with the relevant population segment in the selected eight countries which is below $20 \%$ (aside Italy: 23\%) [49]. A vast majority (79.5\%) of the elderly population choose a private car for their most important daily journey, i.e., going for groceries or running errands (43\%), or going to work (31\%), while only $4 \%$ and $4.5 \%$ opt for public transport and walking, respectively.

Similar to the results for the entire dataset, most of the elderly use a private car to reach their destination because of the time needed, their reliability and the infrequent service of public transport. They would feel comfortable in the presence of AVs if they were travelling in a conventional vehicle, but they would also feel uncomfortable if they were driving a scooter or motorcycle. Proven safety and reliability are the main drivers for the elderly to purchase an $\mathrm{AV}$, while they would be mostly willing to travel in an AV or allow their children to use AVs if an operator was physically present in the vehicle.

To address the range of VRUs within this international survey, a more focused analysis was also carried out on the responses derived from people with disabilities. Table 8 presents valuable insights despite the small sample size ( $\mathrm{N}=53$ ) compared to the global rate ( $3.2 \%$ compared to $15 \%$ globally) [50]. Thirty-seven people indicated having mobility issues, while 16 were visually impaired, and $62.3 \%$ of the respondents use a private car owned by their household for their daily commuting activities. Going to work, to college, or running errands have been identified as the main daily journeys of these respondents. 
Table 7. Responses of the elderly population to various questions affecting mode choice.

\begin{tabular}{|c|c|c|c|c|c|c|}
\hline & $\begin{array}{l}\text { I choose-for my } \\
\text { transport because of } \\
\text { its cost }\end{array}$ & $\begin{array}{l}\text { I choose-for my } \\
\text { transport because of } \\
\text { its reliability }\end{array}$ & $\begin{array}{l}\text { I choose-for my } \\
\text { transport because of } \\
\text { its impact on } \\
\text { the environment }\end{array}$ & $\begin{array}{l}\text { I choose-for my } \\
\text { transport because of } \\
\text { its safety }\end{array}$ & $\begin{array}{l}\text { I choose-for my } \\
\text { transport because of } \\
\text { the time to reach } \\
\text { my destination }\end{array}$ & $\begin{array}{l}\text { I choose-for my } \\
\text { transport because of } \\
\text { the service frequency }\end{array}$ \\
\hline Med & 3 & 6 & 3 & 4 & 6 & 5 \\
\hline \multirow[t]{2}{*}{ IQR } & 2 & 2 & 2 & 2 & 1 & 3 \\
\hline & $\begin{array}{c}\text { I would feel } \\
\text { comfortable in the } \\
\text { presence of AVs near } \\
\text { me if I was } \\
\text { a pedestrian }\end{array}$ & $\begin{array}{l}\text { I would feel } \\
\text { comfortable in the } \\
\text { presence of AVs near } \\
\text { me if I was a cyclist }\end{array}$ & $\begin{array}{l}\text { I would feel } \\
\text { comfortable in the } \\
\text { presence of AVs near } \\
\text { me if I was a } \\
\text { scooter driver }\end{array}$ & $\begin{array}{l}\text { I would feel } \\
\text { comfortable in the } \\
\text { presence of AVs near } \\
\text { me if I was } \\
\text { a motorcyclist }\end{array}$ & $\begin{array}{c}\text { I would feel } \\
\text { comfortable in the } \\
\text { presence of AVs near } \\
\text { me if I was } \\
\text { travelling in a } \\
\text { conventional vehicle }\end{array}$ & $\begin{array}{l}\text { I would feel } \\
\text { comfortable in the } \\
\text { presence of AVs near } \\
\text { me if I was a } \\
\text { passenger in an AV }\end{array}$ \\
\hline Med & 3 & 3 & 2 & 3 & 4 & 4 \\
\hline \multirow[t]{2}{*}{$\mathrm{IQR}$} & 2 & 2 & 2 & 2 & 2.5 & 3 \\
\hline & $\begin{array}{l}\text { I would consider } \\
\text { purchasing an AV as } \\
\text { soon as they } \\
\text { become available }\end{array}$ & $\begin{array}{c}\text { I would consider } \\
\text { purchasing an } \mathrm{AV} \text { as } \\
\text { soon as they } \\
\text { become affordable }\end{array}$ & $\begin{array}{c}\text { I would consider } \\
\text { purchasing an } \mathrm{AV} \text { as } \\
\text { soon as I am } \\
\text { convinced about } \\
\text { their usefulness }\end{array}$ & $\begin{array}{c}\text { I would consider } \\
\text { purchasing an } \mathrm{AV} \text { as } \\
\text { soon as I am } \\
\text { convinced about } \\
\text { their safety }\end{array}$ & $\begin{array}{c}\text { I would consider } \\
\text { purchasing an AV as } \\
\text { soon as I am } \\
\text { convinced about } \\
\text { their reliability }\end{array}$ & $\begin{array}{c}\text { I would consider } \\
\text { purchasing an AV } \\
\text { only after I see them } \\
\text { being used by } \\
\text { others first }\end{array}$ \\
\hline Med & 2 & 2 & 3 & 4 & 4 & 3 \\
\hline \multirow[t]{2}{*}{ IQR } & 2 & 3 & 3 & 3 & 3 & 3 \\
\hline & $\begin{array}{l}\text { I would travel in an } \\
\text { AV (e.g., car, taxi, bus) } \\
\text { with the supervision } \\
\text { of a human operator } \\
\text { in the vehicle }\end{array}$ & $\begin{array}{l}\text { I would travel in an } \\
\text { AV with the remote } \\
\text { supervision of a } \\
\text { human operator at a } \\
\text { distant location }\end{array}$ & $\begin{array}{l}\text { I would travel in an } \\
\text { AV without the } \\
\text { supervision of a } \\
\text { human operator }\end{array}$ & $\begin{array}{l}\text { I would allow my } \\
\text { children to travel in } \\
\text { an AV with the } \\
\text { supervision of a } \\
\text { human operator in } \\
\text { the vehicle }\end{array}$ & $\begin{array}{l}\text { I would allow my } \\
\text { children to travel in } \\
\text { an AV with the } \\
\text { remote supervision of } \\
\text { a human operator at a } \\
\text { distant location }\end{array}$ & $\begin{array}{l}\text { I would allow my } \\
\text { children to travel in } \\
\text { an AV without the } \\
\text { supervision of a } \\
\text { human operator }\end{array}$ \\
\hline Med & 5 & 3 & 2 & 5 & 3 & 2 \\
\hline $\mathrm{IQR}$ & 3 & 3 & 3 & 3 & 3 & 2 \\
\hline
\end{tabular}


Table 8. Responses of people with disabilities to various questions affecting mode choice.

\begin{tabular}{|c|c|c|c|c|c|c|}
\hline & $\begin{array}{l}\text { I choose-for my } \\
\text { transport because of } \\
\text { its cost }\end{array}$ & $\begin{array}{l}\text { I choose-for my } \\
\text { transport because of } \\
\text { its reliability }\end{array}$ & $\begin{array}{l}\text { I choose-for my } \\
\text { transport because of } \\
\text { its impact on } \\
\text { the environment }\end{array}$ & $\begin{array}{l}\text { I choose-for my } \\
\text { transport because of } \\
\text { its safety }\end{array}$ & $\begin{array}{l}\text { I choose-for my } \\
\text { transport because of } \\
\text { the time to reach } \\
\text { my destination }\end{array}$ & $\begin{array}{l}\text { I choose-for my } \\
\text { transport because of } \\
\text { the service frequency }\end{array}$ \\
\hline Med & 2 & 5 & 3 & 3 & 5 & 3 \\
\hline \multirow[t]{2}{*}{$\mathrm{IQR}$} & 3.5 & 4.5 & 2.5 & 3.5 & 3 & 3 \\
\hline & $\begin{array}{c}\text { I would feel } \\
\text { comfortable in the } \\
\text { presence of AVs near } \\
\text { me if I was } \\
\text { a pedestrian }\end{array}$ & $\begin{array}{l}\text { I would feel } \\
\text { comfortable in the } \\
\text { presence of AVs near } \\
\text { me if I was a cyclist }\end{array}$ & $\begin{array}{l}\text { I would feel } \\
\text { comfortable in the } \\
\text { presence of AVs near } \\
\text { me if I was a } \\
\text { scooter driver }\end{array}$ & $\begin{array}{l}\text { I would feel } \\
\text { comfortable in the } \\
\text { presence of AVs near } \\
\text { me if I was } \\
\text { a motorcyclist }\end{array}$ & $\begin{array}{c}\text { I would feel } \\
\text { comfortable in the } \\
\text { presence of AVs near } \\
\text { me if I was } \\
\text { travelling in a } \\
\text { conventional vehicle }\end{array}$ & $\begin{array}{l}\text { I would feel } \\
\text { comfortable in the } \\
\text { presence of AVs near } \\
\text { me if I was a } \\
\text { passenger in an AV }\end{array}$ \\
\hline Med & 3 & 2 & 3 & 3 & 3 & 3 \\
\hline \multirow[t]{2}{*}{$\mathrm{IQR}$} & 3 & 2 & 3 & 3 & 3 & 4 \\
\hline & $\begin{array}{l}\text { I would consider } \\
\text { purchasing an AV as } \\
\text { soon as they } \\
\text { become available }\end{array}$ & $\begin{array}{c}\text { I would consider } \\
\text { purchasing an } \mathrm{AV} \text { as } \\
\text { soon as they } \\
\text { become affordable }\end{array}$ & $\begin{array}{c}\text { I would consider } \\
\text { purchasing an } \mathrm{AV} \text { as } \\
\text { soon as I am } \\
\text { convinced about } \\
\text { their usefulness }\end{array}$ & $\begin{array}{c}\text { I would consider } \\
\text { purchasing an } \mathrm{AV} \text { as } \\
\text { soon as I am } \\
\text { convinced about } \\
\text { their safety }\end{array}$ & $\begin{array}{c}\text { I would consider } \\
\text { purchasing an AV as } \\
\text { soon as I am } \\
\text { convinced about } \\
\text { their reliability }\end{array}$ & $\begin{array}{c}\text { I would consider } \\
\text { purchasing an AV } \\
\text { only after I see them } \\
\text { being used by } \\
\text { others first }\end{array}$ \\
\hline Med & 2 & 3 & 2 & 3 & 3 & 3 \\
\hline \multirow[t]{2}{*}{ IQR } & 2 & 3.5 & 2 & 3.5 & 3 & 2 \\
\hline & $\begin{array}{l}\text { I would travel in an } \\
\text { AV (e.g., car, taxi, bus) } \\
\text { with the supervision } \\
\text { of a human operator } \\
\text { in the vehicle }\end{array}$ & $\begin{array}{l}\text { I would travel in an } \\
\text { AV with the remote } \\
\text { supervision of a } \\
\text { human operator at a } \\
\text { distant location }\end{array}$ & $\begin{array}{l}\text { I would travel in an } \\
\text { AV without the } \\
\text { supervision of a } \\
\text { human operator }\end{array}$ & $\begin{array}{l}\text { I would allow my } \\
\text { children to travel in } \\
\text { an AV with the } \\
\text { supervision of a } \\
\text { human operator in } \\
\text { the vehicle }\end{array}$ & $\begin{array}{l}\text { I would allow my } \\
\text { children to travel in } \\
\text { an AV with the } \\
\text { remote supervision of } \\
\text { a human operator at a } \\
\text { distant location }\end{array}$ & $\begin{array}{l}\text { I would allow my } \\
\text { children to travel in } \\
\text { an AV without the } \\
\text { supervision of a } \\
\text { human operator }\end{array}$ \\
\hline Med & 4 & 3 & 3 & 3 & 3 & 2 \\
\hline $\mathrm{IQR}$ & 4 & 2 & 3 & 3 & 2.5 & 3 \\
\hline
\end{tabular}


Results do not show major differences compared to the elderly groups or general population. However, the overall more reserved responses of people with disabilities compared to the elderly should be stressed, which are in line with [51,52]. In addition, affordability of AVs is among the three main drivers, next to safety and reliability, for people with disabilities to consider purchasing an AV. Finally, unless travellers in a conventional vehicle, these 53 respondents would feel uncomfortable in the presence of an $\mathrm{AV}$ which highlights the need for a particular focus on such potential $\mathrm{AV}$ user needs who will arguably benefit by the deployment of AVs [53].

\section{Discussion}

Results demonstrate that although safety may be among the important factors influencing the decision to use an $\mathrm{AV}$, it is clearly not the only factor and, in some cases, not even the most important one, as argued within this article (Sections 1 and 2). Most respondents prefer a human operator to be present in the vehicle, both when travelling themselves and when their children under the age of 16 are travelling. Our findings demonstrate the importance of safety on users' acceptance of the technology, while it also highlights that a large proportion of respondents do not fully trust SAE Level $5 \mathrm{AVs}$ for their journeys in the absence of human control. When linked with previous experience with automated systems, which in our survey is demonstrated by the use of Adaptive Cruise Control (ACC) as a proxy, it became obvious that past exposure and frequent use of driving assistance technologies increases the trust in more advanced automated vehicle technologies. These findings are in alignment with previous studies, e.g., [11].

Additionally, safety and reliability are among the most decisive factors that will encourage users to purchase an AV. Similarly, this is in line with relevant literature [54] given the slow technological progress in this respect. Reliability features as a key concern for human drivers (see Table 6), so it is not surprising that they would expect the same service provision by an AV. A noteworthy finding of this survey is related to the size of households and their association with the trust in AVs. In fact, initial results show that the larger the household the higher the trust level is in AVs. This finding has not been extensively discussed in the literature yet. Assuming that larger households indicate families with children, it is interesting to further investigate this finding in order to better capture the opinion of people concerning the conditions under which they would allow their children to use AVs. The fact that smaller households appear to have a more reserved approach towards the use of AVs may be attributed to potentially higher level of education and access to information, particularly given the increased awareness (76\%) about AVs compared to 2015 (Section 4.1). Education has been found as a key variable in modal choice [55] and our findings confirm that it plays a role in adopting AVs. In addition, the fact is that in the past two decades young people have started to drive later and the number of younger and smaller households without cars is increasing, which can result in more pessimistic (realistic) expectations of AVs feasibility and lower willingness to use a personal vehicle (regardless of the level of automation) [55,56]. It could also mean that parents (or carers) with more than one child would allow their offspring to travel together in the same AV without the presence of a human operator in the vehicle, as the older children may assist in supervising the younger ones or even call for assistance in case of emergency. These findings are intertwined with safety and may signal a higher value of statistical life by households with fewer members (e.g., single child), whereas larger households may put more trust among their household members when travelling (e.g., siblings). Admittedly, our findings may be considered counterintuitive; thus, future research shall investigate and further compare similar results in countries with traditionally larger households or increasing cultural diversities.

Our survey also stresses the impact of transport automation and digitalization on professional driver jobs e.g., taxi, bus, coach, freight. Findings indicate the worries of the public on the possible transformation of professional driving jobs, from actively driving vehicles to a more supervisory role either in-vehicle or remotely, although it is unclear what safety impact is anticipated through such a transformation. This finding is fully aligned with the findings of the Eurobarometer 2020 
survey [48] and the CAD Employment study [57], stressing the need for relevant policies both in the short- and long-term.

Another factor to potentially hinder the use of $\mathrm{AVs}$ is the unavoidable loss of driving pleasure, which human drivers currently enjoy when driving their own vehicle [55]. Although such behaviours may pose a direct risk to transport safety and accident reduction targets, it is still a notable impact which needs to be considered if wider support for AV deployment is to be sought. Naturally, this issue is of higher importance in certain countries due to their geography, weather or available transport infrastructure. Therefore, more detailed country analysis and an even wider country selection would offer better insight on this matter. Since $90 \%$ of accidents can be attributed to human-errors [54], the added travel safety promised by automated vehicles will not be realized if vehicles continue to be human-driven or if there is an extensive transition period with the co-existence of AVs and conventional vehicles.

Insights on the use of AVs by vulnerable road users were also drawn. The fact that almost $80 \%$ of respondents over 65 years old and more than $60 \%$ of people with disabilities use their private vehicle for their daily commute (mainly due to reliability and infrequent service of public transport) indicates the vast benefits which may be capitalized by these user groups through the deployment of AVs. Our findings confirm the results of Pronello and Camusso [55] showing how an insight in the potential of AVs in fulfilling time constraints, as perceived by elderly people, could be a factor favouring the introduction of $\mathrm{AVs}$ in certain categories of population if they consider that $\mathrm{AVs}$ would be less time consuming. Regardless of their trip purpose-going to work or for groceries-findings suggest that AVs should accommodate the needs of vulnerable road users (Tables 7 and 8 ) ensuring easy access and intuitive interaction. At the same time, it is important to manage the public's expectations regarding the AV deployment and functionalities, while avoiding any negative safety and/or sustainability implications. The increased use of AVs by vulnerable road users, in particular the elderly, may reduce, for instance, public transport ridership which includes a high proportion of elderly across countries. Thus, it is significant for policy makers to consider such findings and adjust relevant policies to support both the uptake of new technologies by all user groups, while meeting national and global sustainability objectives. Finally, this study has also investigated whether people are keen to allow their children to use AVs. Overall, findings are in agreement with previous studies, e.g., [34,36], and indicate that parents would be willing to let their children to use AVs if the vehicles were supervised (in-vehicle or remotely).

\section{Conclusions}

The hype surrounding the introduction and deployment of highly automated driving vehicles has increased over the last ten years; however, the decade ends on a rather pessimistic note [58]. A number of issues related to AV deployment are yet to be addressed, including the concerns of the public over the safety implications of AVs deployment. Safety, however, is not solely responsible for the potential slow uptake of AVs.

By means of an online survey, which follows a two-wave approach, this study highlighted the importance of factors other than safety on public acceptance of AVs and potential uptake of the automated technology, based on information collected in Spring 2020 from eight European countries (first wave). The survey's second wave, which started in September 2020, will be in progress until it reaches 14 countries. In the second wave, the survey is again open to the countries reached in the first wave, to allow an increase of the number of respondents and have, at the end, a panel of 14 countries with, at least, 300 answers per country.

Overall, it has been demonstrated that factors such as reliability, affordability, cost, driving pleasure and household size may affect AVs uptake; thus, they should not be neglected when designing policies on AVs introduction and deployment. AVs shall be designed accounting for the needs of vulnerable road users, ranging from young children to the elderly and people with disabilities. Considering the needs of vulnerable road users at an early stage of the vehicle design can generate revenue streams of 
niche user groups who depend strongly on mobility and may spend considerable proportions of their income to satisfy their mobility needs.

Our results, which are largely in alignment with previous research, e.g., [25,27,57], can be used by policy makers and other actors in the field of AVs development and deployment in order to address the following issues (in addition to safety). First, to ensure AVs reliability and how to better meet the expectations of their potential users. Second, how to ensure affordability of AVs, either as private vehicles or as shared modes of transport, for the majority of the population. Third, how to better communicate the AVs functionalities, and how to better design AVs for those who have not been exposed to automated features or have special needs to use them. Fourth, how to demonstrate to the public the usefulness of $\mathrm{AVs}$ and how to best display their advantages, e.g., increased mobility for all, reduced stress of driving, reduced traffic congestion, improved navigation and smoother/faster driving times [43].

It shall also be noted that many of the identified factors also apply to conventional vehicles, so actions may be taken even prior to the deployment of AVs in tandem with sustainability objectives. The need for coordinated approaches at city, regional, national and international levels both in the Global North and the Global South [27] is pertinent due to the 2030 Sustainable Development Goals and the long-term implications of AVs. With coordinated actions and policies, it will be possible to address inherent inequalities of the transport system [29] through new technological developments, whilst at the same time meeting common sustainability goals worldwide.

Despite the useful insights, this study has certain limitations. First, most of the survey's participants were male, which does not necessarily represent the national gender quota. Further, males are usually more open to accepting new technologies [59]; thus, findings shall be critically revisited in follow-up studies which may include a more balanced gendered sample. Second, an online survey does by default exclude a part of the population that has no access to or is not familiar with the internet (especially the elderly) [60]. Therefore, findings have to be contrasted with a survey conducted by telephone or mail to capture the opinion of people who are not keen to, may have not access to or simply do not use the internet. Third, although insights on the use of AVs by children were drawn from the data, no children had actually participated in the survey due to the applicable research ethics framework. To address this drawback future studies would benefit by contacting and asking minors on their opinion on AVs since they will most likely be affected by the anticipated deployment of AVs in the coming decades.

Regardless of the acknowledged limitations, we expect that our findings are relevant for all stakeholders involved with the development of automated driving technology and contribute to the safety debate surrounding AVs.

Author Contributions: Conceptualization, M.K., K.S., J.S. and N.T.; Methodology, M.K., K.S., C.P. and N.T.; Formal Analysis, M.K., K.S. and A.B.E.; Resources, N.T.; Data Curation, M.K., N.T. and A.B.E.; Writing-Original Draft Preparation, M.K., K.S., J.S., A.B.E. and N.T.; Writing-Review and Editing, M.K., K.S., J.S., A.B.E., N.T. and C.P.; Visualization, A.B.E.; Supervision, M.K. and C.P.; Project Administration, M.K.; Funding Acquisition, N.T. All authors have read and agreed to the published version of the manuscript.

Funding: This research and the APC were funded by the WISE-ACT COST Action CA16222.

Acknowledgments: The authors would like to acknowledge the support provided by the WISE-ACT COST Action CA16222 which supported financially this survey and facilitated the development of this article through meetings, workshops and Training Schools.

Conflicts of Interest: The authors declare no conflict of interest. 


\section{Appendix A}

Table A1. Responses regarding participants' households.

\begin{tabular}{cccc}
\hline & & Total & Share \\
\hline & & $\mathbf{1 6 3 9}$ & $\mathbf{1 0 0} \%$ \\
\hline \multirow{3}{*}{ Household size } & 1 person & 207 & $12.6 \%$ \\
& 2 persons & 415 & $25.3 \%$ \\
& 3 persons & 310 & $18.9 \%$ \\
& 4 persons & 426 & $26.0 \%$ \\
& 5 and more & 281 & $17.1 \%$ \\
\hline Household members needing care & None & 1105 & $67.4 \%$ \\
& 1 person & 219 & $13.4 \%$ \\
& 2 persons & 199 & $12.1 \%$ \\
& 3 and more & 116 & $7.1 \%$ \\
\hline \multirow{2}{*}{ Cars in household } & 0 & 101 & $6.2 \%$ \\
& 1 & 621 & $37.9 \%$ \\
& 2 & 625 & $38.1 \%$ \\
& 3 & 185 & $11.3 \%$ \\
& 4 and more & 105 & $6.4 \%$ \\
\hline
\end{tabular}

Table A2. Responses regarding participants' driving behaviour.

\begin{tabular}{|c|c|c|c|}
\hline & & Total & Share \\
\hline & & 1639 & $100 \%$ \\
\hline \multirow{5}{*}{$\begin{array}{l}\text { In how many accidents have you } \\
\text { been involved in the last } 3 \text { years? }\end{array}$} & 0 & 1250 & $76 \%$ \\
\hline & 1 & 270 & $16 \%$ \\
\hline & 2 & 71 & $4 \%$ \\
\hline & 3 and more & 33 & $2 \%$ \\
\hline & Does not disclose & 15 & $1 \%$ \\
\hline \multirow{11}{*}{$\begin{array}{l}\text { How often did you use ACC while } \\
\text { driving in the last } 12 \text { months? }\end{array}$} & Every day & 85 & $5 \%$ \\
\hline & 4 to 6 days a week & 36 & $2 \%$ \\
\hline & 1 to 3 days a week & 72 & $4 \%$ \\
\hline & About once a fortnight & 57 & $3 \%$ \\
\hline & About once a month & 48 & $3 \%$ \\
\hline & Less than once a month & 113 & $7 \%$ \\
\hline & Never & 446 & $27 \%$ \\
\hline & The car I am using does not have ACC & 580 & $35 \%$ \\
\hline & I do not drive a car & 90 & $5 \%$ \\
\hline & I do not know what ACC is & 29 & $2 \%$ \\
\hline & Does not disclose & 83 & $5 \%$ \\
\hline
\end{tabular}


Table A3. Responses regarding participants' important trips.

\begin{tabular}{|c|c|c|c|}
\hline & & Total & Share \\
\hline & & 1639 & $100 \%$ \\
\hline \multirow{9}{*}{$\begin{array}{l}\text { Think of a typical week of yours. } \\
\text { What is the purpose of the most } \\
\text { important journey of yours? }\end{array}$} & Go to work & 948 & $58 \%$ \\
\hline & Other professional reasons (e.g., Business trips) & 67 & $4 \%$ \\
\hline & Go to School or College or University or other educational activity & 244 & $15 \%$ \\
\hline & Groceries, errands, administrative purposes, medical appointment & 150 & $9 \%$ \\
\hline & Pick-up or drop-off someone & 42 & $3 \%$ \\
\hline & Visiting someone (e.g., Friends or relatives) & 48 & $3 \%$ \\
\hline & Leisure (e.g., Sports, cultural activities) & 87 & $5 \%$ \\
\hline & No important journey & 34 & $2 \%$ \\
\hline & Other & 19 & $1 \%$ \\
\hline \multirow{12}{*}{$\begin{array}{l}\text { What is the main mode of } \\
\text { transport you use for this } \\
\text { important journey of yours? }\end{array}$} & Private car (owned by myself or someone in my household) & 1111 & $68 \%$ \\
\hline & Shared car (e.g., a car which is shared with other travellers) & 42 & $3 \%$ \\
\hline & Public transport (e.g., bus, tram, underground, metro, train) & 179 & $11 \%$ \\
\hline & Shuttle service to work & 17 & $1 \%$ \\
\hline & Private bicycle (owned by myself or someone in my household) & 120 & $7 \%$ \\
\hline & Shared bicycle (e.g., through my city bicycle sharing scheme) & 3 & $0 \%$ \\
\hline & Motorbike (owned by myself or someone in my household) & 18 & $1 \%$ \\
\hline & Shared motorbike (a shared motorbike) & 1 & $0 \%$ \\
\hline & Scooter & 5 & $0 \%$ \\
\hline & Walking & 82 & $5 \%$ \\
\hline & None, as I do not have any important journey & 1 & $0 \%$ \\
\hline & Other & 26 & $2 \%$ \\
\hline
\end{tabular}

Table A4. Responses on participants' experience with autonomous vehicles.

\begin{tabular}{cccc}
\hline & & Total & Share \\
\hline & & $\mathbf{1 6 3 9}$ & $\mathbf{1 0 0 \%}$ \\
\hline In the last twelve months, have you heard, read or & Yes & 1249 & $76 \%$ \\
seen anything about Autonomous Vehicles? & No & 341 & $21 \%$ \\
& I do not know & 49 & $3 \%$ \\
\hline Have you ever travelled in an Autonomous Vehicle? & Yes & 177 & $11 \%$ \\
& No & 1426 & $87 \%$ \\
& I do not know & 36 & $2 \%$ \\
\hline
\end{tabular}

\section{References}

1. Boyce, T.E.; Geller, E.S. An instrumented vehicle assessment of problem behavior and driving style: Do younger males really take more risks? Accid. Anal. Prev. 2002, 34, 51-64. [CrossRef]

2. Smith, B.W. Human Error as a Cause of Vehicle Crashes. 2013. Available online: http://cyberlaw.stanford. edu/blog/2013/12/human-error-cause-vehicle-crashes (accessed on 31 October 2020).

3. Sabey, B.E.; Taylor, H. The Known Risks We Run: The Highway. In Societal Risk Assessment; Schwing, R.C., Albers, W.A., Eds.; Springer: Boston, MA, USA, 1980; pp. 43-70.

4. SAE International. Taxonomy and Definitions for Terms Related to Driving Automation Systems for On-Road Motor Vehicles; J3016; SAE International: Warrendale, PA, USA, 2016.

5. Thierer, A.D.; Watney, C.J. Comment on the Federal Automated Vehicles Policy. SSRN Electron. J. 2016. [CrossRef]

6. Stayton, E.; Stilgoe, J. It's Time to Rethink Levels of Automation for Self-Driving Vehicles. SSRN Electron. J. 2020. [CrossRef]

7. Wadud, Z.; MacKenzie, D.; Leiby, P. Help or hindrance? The travel, energy and carbon impacts of highly automated vehicles. Transp. Res. Part A Policy Pr. 2016, 86, 1-18. [CrossRef]

8. Clements, L.M.; Kockelman, K.M. Economic Effects of Automated Vehicles. Transp. Res. Rec. J. Transp. Res. Board 2017, 2606, 106-114. [CrossRef]

9. Greenblatt, J.B.; Shaheen, S. Automated Vehicles, On-Demand Mobility, and Environmental Impacts. Curr. Sustain. Energy Rep. 2015, 2, 74-81. [CrossRef] 
10. Hudson, A. United Nations Development Program (UNDP) perspectives on global large marine ecosystems movement. Environ. Dev. 2016, 17, 330-331. [CrossRef]

11. Kyriakidis, M.; Happee, R.; De Winter, J. Public opinion on automated driving: Results of an international questionnaire among 5000 respondents. Transp. Res. Part F Traffic Psychol. Behav. 2015, 32, 127-140. [CrossRef]

12. Rödel, C.; Stadler, S.; Meschtscherjakov, A.; Tscheligi, M. Towards autonomous cars: The effect of autonomy levels on acceptance and user experience. In Proceedings of the 6th International Conference on Automotive User Interfaces and Interactive Vehicular Applications, Seattle, WA, USA, 17-19 September 2014; Association for Computing Machinery (ACM): New York, NY, USA, 2014; pp. 1-8.

13. Schoettle, B.; Sivak, M. Public Opinion about Self-Driving Vehicles in China, India, Japan, the US, the UK, and Australia; University of Michigan, Ann Arbor, Transportation Research Institute: Ann Arbor, MI, USA, 2014.

14. Etzioni, S.; Hamadneh, J.; Elvarsson, A.B.; Esztergár-Kiss, D.; Djukanovic, M.; Neophytou, S.N.; Sodnik, J.; Pronello, C.; Thomopoulos, N.; Shiftan, Y. Modeling cross-national differences in automated vehicle acceptance. Sustainability 2020. under review.

15. Kalra, N.; Groves, D. The Enemy of Good: Estimating the Cost of Waiting for Nearly Perfect Automated Vehicles; Rand Corporation: Santa Monica, CA, USA, 2017.

16. Fraedrich, E.; Lenz, B. Automated driving: Individual and societal aspects. Trans. Res. Rec. 2014, $2416,64-72$. [CrossRef]

17. Haboucha, C.J.; Ishaq, R.; Shiftan, Y. User preferences regarding autonomous vehicles. Transp. Res. Part C Emerg. Technol. 2017, 78, 37-49. [CrossRef]

18. Nordhoff, S.; De Winter, J.; Kyriakidis, M.; Van Arem, B.; Happee, R. Acceptance of Driverless Vehicles: Results from a Large Cross-National Questionnaire Study. J. Adv. Transp. 2018, 2018, 1-22. [CrossRef]

19. Costantini, F.; Thomopoulos, N.; Steibel, F.; Curl, A.; Lugano, G.; Kováčiková, T. Autonomous vehicles in a GDPR era: An international comparison. Adv. Trans. Policy Plan. 2020, 5, 191-213. [CrossRef]

20. Wider Impacts and Scenarios Evaluation of Autonomous and Connected Transport-WISE-ACT. Available online: https://wise-act.eu/ (accessed on 2 November 2020).

21. Fisher, M.; Savirimuthu, J.; Reed, N. Misplaced Trust? Eng. Technol. Ref. 2015, 1, 1-7. [CrossRef]

22. Intelligent Transport Systems. ITS \& Vulnerable Road Users. Available online: https://ec.europa.eu/transport/ themes/its/road/action_plan/its_and_vulnerable_road_users_en (accessed on 2 November 2020).

23. Harper, C.D.; Hendrickson, C.T.; Mangones, S.; Samaras, C. Estimating potential increases in travel with autonomous vehicles for the non-driving, elderly and people with travel-restrictive medical conditions. Transp. Res. Part C Emerg. Technol. 2016, 72, 1-9. [CrossRef]

24. Rhiu, I.; Kwon, S.; Bahn, S.; Yun, M.H.; Yu, W. Research Issues in Smart Vehicles and Elderly Drivers: A Literature Review. Int. J. Hum.-Comput. Interact. 2015, 31, 635-666. [CrossRef]

25. Anderson, J.; Kalra, N.; Stanley, K.; Sorensen, P.; Samaras, C.; Oluwatola, T. Autonomous Vehicle Technology: How to Best Realize Its Social Benefits; Rand Corporation: Santa Monica, CA, USA, 2014; p. 16.

26. Cohen, S.A.; Hopkins, D. Autonomous vehicles and the future of urban tourism. Ann. Tour. Res. 2019, 74, 33-42. [CrossRef]

27. Milakis, D.; Thomopoulos, N.; van Wee, B. Policy Implications of Autonomous Vehicles. Adv. Trans. Policy Plan. 2020, 5, 318-322.

28. Nikitas, A.; Njoya, E.T.; Dani, S. Examining the myths of connected and autonomous vehicles: Analysing the pathway to a driverless mobility paradigm. Int. J. Automot. Technol. Manag. 2019, 19, 10-30. [CrossRef]

29. Thomopoulos, N.; Nikitas, A. Special Issue on: Smart Urban Mobility Futures. Int. J. Automot. Technol. Manag. 2019, 19, 1-9.

30. Zeng, Z.; Chen, P.-J.; Lew, A.A. From high-touch to high-tech: COVID-19 drives robotics adoption. Tour. Geogr. 2020, 22, 724-734. [CrossRef]

31. Okyere, M.A.; Forson, R.; Essel-Gaisey, F. Positive externalities of an epidemic: The case of the coronavirus (COVID-19) in China. J. Med. Virol. 2020, 92, 1376-1379. [CrossRef]

32. Thomopoulos, N.; Givoni, M. The autonomous car-A blessing or a curse for the future of low carbon mobility? An exploration of likely vs. desirable outcomes. Eur. J. Futures Res. 2015, 3, 1-14. [CrossRef]

33. Tremoulet, P.D.; Seacrist, T.; McIntosh, C.W.; Loeb, H.; DiPietro, A.; Tushak, S. Transporting Children in Autonomous Vehicles: An Exploratory Study. Hum. Fact. J. Hum. Fact. Ergon. Soc. 2019, 62, 278-287. [CrossRef] 
34. Lee, Y.-C.; Mirman, J.H. Parents' perspectives on using autonomous vehicles to enhance children's mobility. Transp. Res. Part C Emerg. Technol. 2018, 96, 415-431. [CrossRef]

35. Guanetti, J.; Kim, Y.; Borrelli, F. Control of connected and automated vehicles: State of the art and future challenges. Annu. Rev. Control. 2018, 45, 18-40. [CrossRef]

36. Hand, S.; Lee, Y.-C. Who Would Put Their Child Alone in an Autonomous Vehicle? Preliminary Look at Gender Differences. Proc. Hum. Fact. Ergon. Soc. Annu. Meet. 2018, 62, 256-259. [CrossRef]

37. Schwebel, D.C. Child/Adolescent development and autonomous vehicle operation: "operator's licenses" instead of driver's licenses. J. Inj. Violence Res. 2018, 10, 61. [CrossRef]

38. Matsumi, R.; Raksincharoensak, P.; Nagai, M. Development of Autonomous Intelligent Driving System to Enhance Safe and Secured Traffic Society for Elderly Drivers-Autonomous Collision Avoidance System with Hazard Anticipation Driver Characteristics. J. Robot. Mechatron. 2013, 25, 966-972. [CrossRef]

39. Yang, J.; Coughlin, J.F. In-vehicle technology for self-driving cars: Advantages and challenges for aging drivers. Int. J. Automot. Technol. 2014, 15, 333-340. [CrossRef]

40. Baldwin, C.L. Designing in-vehicle technologies for older drivers: Application of sensory-cognitive interaction theory. Theor. Issues Ergon. Sci. 2002, 3, 307-329. [CrossRef]

41. Guo, J.; Susilo, Y.; Antoniou, C.; Brenden, A.P. Influence of Individual Perceptions on the Decision to Adopt Automated Bus Services. Sustainability 2020, 12, 6484. [CrossRef]

42. Thomopoulos, N.; Harrison, G. An ethical assessment of low carbon vehicles using cost benefit analysis. Int. J. Automot. Technol. Manag. 2016, 16, 227-247. [CrossRef]

43. Tay, G.; Pronello, C. People perceptions and public acceptance of autonomous vehicles: A literature review. In Proceedings of the 8th Transport Research Arena TRA, Helsinki, Finland, 27-30 April 2020.

44. Elvik, R. The demand for automated vehicles: A synthesis of willingness-to-pay surveys. Econ. Transp. 2020, 23, 100179. [CrossRef]

45. Rahimi, A.; Azimi, G.; Jin, X. Examining human attitudes toward shared mobility options and autonomous vehicles. Transp. Res. Part F Traffic Psychol. Behav. 2020, 72, 133-154. [CrossRef]

46. Hensher, D.A. What might Covid-19 mean for mobility as a service (MaaS)? Transp. Rev. 2020, 40, 551-556. [CrossRef]

47. Nordhoff, S.; De Winter, J.; Madigan, R.; Merat, N.; Van Arem, B.; Happee, R. User acceptance of automated shuttles in Berlin-Schöneberg: A questionnaire study. Transp. Res. Part F Traffic Psychol. Behav. 2018, 58, 843-854. [CrossRef]

48. European Commission. Expectations and Concerns of Connected and Automated Driving. Special Eurobarometer April. Available online: https:/trimis.ec.europa.eu/content/eurobarometer-surveyexpectations-and-concerns-connected-and-automated-driving (accessed on 31 October 2020).

49. The World Bank. Population Ages 65 and above (\% of Total Population). 2017. Available online: https://data. worldbank.org/indicator/SP.POP.65UP.TO.ZS?name_desc=false\&view=chart (accessed on 31 October 2020).

50. Krahn, G.L. WHO World Report on Disability: A review. Disabil. Heal. J. 2011, 4, 141-142. [CrossRef]

51. Bennett, R.; Vijaygopal, R.; Kottasz, R. Attitudes towards autonomous vehicles among people with physical disabilities. Transp. Res. Part A Policy Pr. 2019, 127, 1-17. [CrossRef]

52. Bennett, R.; Vijaygopal, R.; Kottasz, R. Willingness of people who are blind to accept autonomous vehicles: An empirical investigation. Transp. Res. Part F Traffic Psychol. Behav. 2020, 69, 13-27. [CrossRef]

53. Claypool, H.; Bin-Nun, A.; Gerlach, J. Self-Driving Cars: The Impact on People with Disabilities; Ruderman Family Foundation: Newton, MA, USA, 2017.

54. Fagnant, D.J.; Kockelman, K.M. Preparing a nation for autonomous vehicles: Opportunities, barriers and policy recommendations. Transp. Res. Part A Policy Pr. 2015, 77, 167-181. [CrossRef]

55. Pronello, C.; Camusso, C. Travellers' profiles definition using statistical multivariate analysis of attitudinal variables. J. Transp. Geogr. 2011, 19, 1294-1308. [CrossRef]

56. Alessandrini, A.; Campagna, A.; Site, P.D.; Filippi, F.; Persia, L. Automated Vehicles and the Rethinking of Mobility and Cities. Transp. Res. Procedia 2015, 5, 145-160. [CrossRef]

57. Ecorys. Connected and Automated Driving: Social Impacts and Policy Options; Workshop: Brussels, Belgium, 2020.

58. McFarland, M. Self-Driving Cars: Hype-Filled Decade Ends on Sobering Note. CNN Business, 18 December 2019. Available online: https://edition.cnn.com/2019/12/18/tech/self-driving-cars-decade/index.html (accessed on 31 October 2020). 
59. Goswami, A.; Dutta, S. Gender Differences in Technology Usage-A Literature Review. Open J. Bus. Manag. 2016, 4, 51-59. [CrossRef]

60. Morris, A.; Goodman, J.; Brading, H. Internet use and non-use: Views of older users. Univ. Access Inf. Soc. 2007, 6, 43-57. [CrossRef]

Publisher's Note: MDPI stays neutral with regard to jurisdictional claims in published maps and institutional affiliations.

(C) 2020 by the authors. Licensee MDPI, Basel, Switzerland. This article is an open access article distributed under the terms and conditions of the Creative Commons Attribution (CC BY) license (http://creativecommons.org/licenses/by/4.0/). 